\title{
LAW IS A TOOL OF SOCIAL ENGINEERING DALAM PENANGANAN TINDAK PIDANA KORUPSI DI INDONESIA DITINJAU DARI HUKUM ISLAM DAN PERUNDANG-UNDANGAN DI INDONESIA
}

\author{
Martha Eri Safira*
}

\begin{abstract}
Abstrak
Tindak pidana korupsi merupakan suatu masalah sangat serius dan perlu diperhatikan, karena tindak pidana korupsi dapat membahayakan stabilitas dan keamanan negara dan masyarakatnya, membahayakan pembangunan sosial dan ekonomi masyarakat, politik, bahkan dapat pula merusak nilai-nilai demokrasi serta moralitas bangsa karena dapat berdampak membudayanya tindak pidana korupsi.

Korupsi dalam Islam digolongkan sebagai suatu perbuatan yang tercela dan sangat merugikan orang lain maupun bangsa Indonesia serta pelakunya termasuk sebagai orang-orang yang munafik, dzalim, kafir, dan merupakan dosa yang besar karena mereka telah memakan atau mengambil sesuatu yang bukan haknya atau bukan miliknya dan ancaman hukumannya adalah neraka jahanam. Alloh SWT melarang umatnya untuk memakan atau mengambil harta maupun hak orang lain dengan cara yang tidak halal, baik melalui pencurian, copet, rampok, pemerasan, pemaksaan, ataupun bentuk-betuk lainnya. Pandangan Al Qur'an tentang korupsi sangatlah tegas yaitu haram, karena termasuk dalam memakan harta sesama dengan cara yang tidak halal. Penegakkan hukum terhadap Undang-Undang Korupsi masih sangat sulit diterapkan di Indonesia. Oleh sebab itu Undang-Undang No. 31 Tahun 1999 jo. Undang-Undang No. 20 Tahun 2001 tentang Pencegahan dan Penanggulangan Tindak Pidana Korupsi (disingkat UU Korupsi) harus bisa menjadi sarana rekayasa sosial bagi masyarakat. Serta bagaimana hukum Islam juga bisa menjadi kontrol sosial untuk membantu pemerintah dalam menerapkan efek jera bagi pelaku tindak pidana korupsi.
\end{abstract}

Kata kunci: korupsi, social engineering, hukum Islam, UndangUndang Korupsi 


\section{PENDAHULUAN}

Tindak pidana korupsi merupakan perbuatan yang berdampak sangat besar bagi masyarakat dan peradabannya. Akan tetapi hal ini, tidak dipahami benar oleh masyarakat, khususnya di Indonesia. Di Indonesia, tindak pidana korupsi sudah sangat meluas dan telah masuk sampai ke seluruh lapisan masyarakat. Perkembangan tindak pidana korupsi ini terus meningkat dari tahun ke tahun, terhitung banyaknya jumlah kasus yang terjadi dan jumlah kerugian keuangan negara, serta tindak pidana korupsi yang dilakukan semakin sistematis yang telah memasuki seluruh aspek kehidupan masyarakat yang dilihat dari segi kualitas. ${ }^{1}$

Tindak pidana korupsi di Indonesia sudah tidak terkendali lagi. bahkan dalam berbagai macam survey, Indonesia masuk dalam salah satu daftar negara terkorup di dunia. Berbagai macam kasus korupsi mulai dari yang besar, sedang hingga kasus kecil terjadi tahun demi tahun secara terus menerus tanpa bisa dihentikan. Hukuman yang ringan menjadi penyebab utama para koruptor tetap saja menjalankan aksinya. Hukum yang diandalkan juga belum mampu bekerja maksimal, malahan kini hukum sangat mudah untuk dibeli. Hal ini bisa dilihat dari banyaknya aparat hukum yang terlibat kasus suap. Negara pun menanggung kerugian mulai dari ratusan juta, milyaran hingga trilyunan rupiah. berbagai macam kasus korupsi kebanyakan tidak menghasilkan hukuman yang membuat jerah para pelaku/tersangka korupsi. Kasus-kasus tindak pidana korupsi besar yang ada di Indonesia, dan yang belum terpecahkan sampai sekarang adalah Kasus Bank Century, Kasus BLBI, Korupsi dana haji yang menjerat mantan Menteri Agama Suryadharma Ali, Dugaan korupsi pengadan tanah RS Sumber Waras oleh Gubernur Basuki Tjahya Purnama, dan Mega korupsi kasus penyelenggaraan E-KTP.

Kasus pertama, kasus BI, yang pada masa itu sebagai Gubernur adalah Budiono, diduga mengubah persyaratan CAR. Dengan maksud, Bank Century bisa mendapatkan Fasilitas Pendanaan Jangka Pendek (FPJP). Kemudian, soal keputusan Komite Stabilitas Sistem Keuangan (KKSK)-saat itu diketuai Menkeu Sri Mulyanidalam menangani Bank Century, tidak didasari data yang lengkap.

${ }^{1}$ Ermansjah Djaja, Memberantas Korupsi Bersama KPK (Komisi Pemberantasan Korupsi) (Jakarta: Sinar Grafika, 2009), 35. 
Pada saat penyerahan Bank Century, 21 November 2008, belum dibentuk berdasar UU. Lembaga Penjamin Simpanan (LPS) juga diduga melakukan rekayasa peraturan agar Bank Century mendapat tambahan dana. Beberapa hal kemudian terungkap pula, saat Bank Century dalam pengawasan khusus, ada penarikan dana sebesar Rp938 miliar yang tentu saja, menurut BPK, melanggar peraturan BI. Pendek kata, terungkap beberapa praktik perbankan yang tidak sehat. $^{2}$

Kasus kedua, kasus Bantuan Likuiditas Bank Indonesia (BLBI) yang pertama kali mencuat ketika Badan Pemeriksa Keuangan mengungkapkan hasil auditnya pada Agustus 2000. Laporan itu menyebut adanya penyimpangan penyaluran dana BLBI Rp138,4 triliun dari total dana senilai Rp144,5 triliun. Di samping itu, disebutkan adanya penyelewengan penggunaan dana BLBI yang diterima 48 bank sebesar Rp80,4 triliun. Bekas Gubernur Bank Indonesia Soedradjad Djiwandono dianggap bertanggung jawab dalam pengucuran BLBI. Sebelumnya, mantan pejabat BI lainnya yang terlibat pengucuran BLBI, Hendrobudiyanto, Paul Sutopo, dan Heru Soepraptomo, telah dijatuhi hukuman masing-masing tiga, dua setengah, dan tiga tahun penjara, yang dianggap terlalu ringan oleh para pengamat. Ketiganya kini sedang naik banding. Bersama tiga petinggi $\mathrm{BI}$ itu, pemilik-komisaris dari 48 bank yang terlibat BLBI, hanya beberapa yang telah diproses secara hukum. Antara lain: Hendrawan Haryono (Bank Aspac), David Nusa Widjaja (Bank Servitia), Hendra Rahardja (Bank Harapan Santosa), Sjamsul Nursalim (BDNI), dan Samadikun Hartono (Bank Modern). ${ }^{3}$ Korupsi PSO USO dana PNBP Telco di BP3TI Kominfo, rugikan negara 3 Triliun.

Ketiga, kasus korupsi dana haji yang menjerat mantan Menteri Agama Suryadharma Ali. Suryadharma diyakini Jaksa KPK melakukan tindak pidana korupsi dalam penyelenggaraan ibadah haji tahun 2010-2013 mulai dari penentuan petugas haji, pengangkatan petugas pendamping amirul hajj, pemondokan, memanfaatkan sisa kuota haji. Suryadharma juga diyakini Jaksa KPK menyelewengkan dana operasional menteri Rp1,8 miliar. Akibat perbuatannya tersebut

${ }^{2}$ https://nasional.tempo.co

${ }^{3}$ https://nasional.tempo.co 
negara mengalami kerugian keuangan sebesar Rp27.283.090.068 dan SR 17.967.405. Hukuman yang diterima berupa pidana penjara selama 6 tahun dikurangi selama terdakwa berada di dalam tahanan ditambah dengan pidana denda sebesar Rp300 juta subsider 3 bulan kurungan," kata Ketua Majelis Hakim Aswijon dalam sidang pembacaan vonis di pengadilan Tindak Pidana Korupsi (Tipikor) Jakarta Pusat. ${ }^{4}$

Melihat banyaknya kasus-kasus korupsi yang terjadi di Indonesia dan betapa ringan hukuman (pidana) yang dijatuhkan, mengakibatkan tindak pidana korupsi di Indonesia sulit untuk diberantas. Penegakkan hukum terhadap Undang-Undang Korupsi masih sangat sulit diterapkan di Indonesia. Oleh sebab itu UndangUndang No. 31Tahun 1999 jo. Undang-Undang No. 20 Tahun 2001 tentang Pencegahan dan Penanggulangan Tindak Pidana Korupsi (disingkat UU Korupsi) harus bisa menjadi sarana rekayasa sosial bagi masyarakat. Serta bagaimana hukum Islam juga bisa menjadi kontrol sosial untuk membantu pemerintah dalam menerapkan efek jera bagi pelaku tindak pidana korupsi.

Korupsi dalam Islam digolongkan sebagai suatu perbuatan yang tercela dan sangat merugikan orang lain maupun bangsa Indonesia serta pelakunya termasuk sebagai orang-orang yang munafik, dzalim, kafir, dan merupakan dosa yang besar karena mereka telah memakan atau mengambil sesuatu yang bukan haknya atau bukan miliknya dan ancaman hukumannya adalah neraka jahanam. Alloh SWT melarang umatnya untuk memakan atau mengambil harta maupun hak orang lain dengan cara yang tidak halal, baik melalui pencurian, copet, rampok, pemerasan, pemaksaan, ataupun bentuk-bentuk lainnya. Pandangan Al-Qur'an tentang korupsi sangatlah tegas yaitu haram, karena termasuk dalam memakan harta sesama dengan cara yang tidak halal. ${ }^{5}$ Beberapa jenis tindak pidana (jarimah) dalam fiqh jinayah dari unsur-unsur dan definisi yang mendekati pengertian korupsi di masa sekarang adalah: Ghulul (Penggelapan), Risywah (Penyuapan), Ghasab (Mengambil Paksa Hak/Harta Orang Lain), Khianat, Sariqah (Pencurian), Hirabah (Perampokan), Al-

${ }^{4}$ https://nasional.tempo.co/read/news/2016/01/11/063735036/suryadharma-alidivonis-6-tahun-penjara

${ }^{5}$ A. Hanafi Azas-Azas Hukum Pidana Islam(Jakarta: Bulan Bintang, 1993), 69. 
Maks (Pungutan Liar), Al-Ikhtilas (Pencopetan), dan Al-Ihtihab (Perampasan). ${ }^{6}$

Rescou Pound menyatakan bahwa rekayasa sosial diperlukan untuk menguatkan peradaban masyarakat manusia karena mengendalikan perilaku antisosial yang bertentangan dengan kaidah-kaidah ketertiban sosial. Hukum, sebagai mekanisme kontrol sosial, merupakan fungsi utama dari negara dan bekerja melalui penerapan kekuatan yang dilaksanakan secara sistematis dan teratur oleh agen yang ditunjuk untuk melakukan fungsi itu. Akan tetapi, Pound menambahkan bahwa hukum saja tidak cukup, ia membutuhkan dukungan dari institusi keluarga, pendidikan, moral, dan agama. Hukum adalah sistem ajaran dengan unsur ideal dan empiris, yang menggabungkan teori hukum kodrat dan positivistik. ${ }^{7}$ Adanya ketentuan yang telah dinashkan dalam al-Qur'an dan al hadits tentang korupsi dan dfi dalam aturan perundang-undangan, seharusnya mampu untuk meminimalisir tindak pidana korupsi.

\section{PEMBAHASAN}

\section{Konsep Law Is A Tool of Social Engineering}

Roscoe Pound adalah ahli hukum pertama menganalisis yurisprudensi serta metodologi ilmu-ilmu sosial. Hingga saat itu, filsafat yang telah dianut selama berabad-abad dituding telah gagal dalam menawarkan teori semacam itu, fungsi logika sebagai sarana berpikir semakin terabaikan dengan usaha-usaha yang dilakukan oleh Langdell serta para koleganya dari Jerman. Pound menyatakan bahwa hukum adalah lembaga terpenting dalam melaksanakan kontrol sosial. Hukum secara bertahap telah menggantikan fungsi agama dan moralitas sebagai instrumen penting untuk mencapai ketertiban sosial. Menurutnya, kontrol sosial diperlukan untuk melestarikan peradaban karena fungsi utamanya adalah mengendalikan "aspek internal atau sifat manusia”, yang dianggapnya sangat diperlukan untuk menaklukkan aspek eksternal atau lingkungan fisikal. ${ }^{8}$

${ }^{6}$ Noeh, M. Fuad, Islam dan Gerakan Moral Anti Korupsi (Jakarta: Zikrul Hakim, 1997), 154-155.

${ }^{7}$ Leden Marpaung, Tindak Pidana Korupsi (Jakarta: Sinar Grafika, 1992), 149.

${ }^{8}$ Lili Rasjidi dan Ira Thania Rasjidi, Dasar-dasar Filsafat dan Teori Hukum (Bandung: Citra Aditya Bakti, 2007), 74. 
Pound menyatakan bahwa kontrol sosial diperlukan untuk menguatkan peradaban masyarakat manusia karena mengendalikan perilaku antisosial yang bertentangan dengan kaidah-kaidah ketertiban sosial. Hukum, sebagai mekanisme control sosial, merupakan fungsi utama dari negara dan bekerja melalui penerapan kekuatan yang dilaksanakan secara sistematis dan teratur oleh agen yang ditunjuk untuk melakukan fungsi itu. Akan tetapi, Pound menambahkan bahwa hukum saja tidak cukup, ia membutuhkan dukungan dari institusi keluarga, pendidikan, moral, dan agama. Hukum adalah sistem ajaran dengan unsur ideal dan empiris, yang menggabungkan teori hukum kodrat dan positivistik. ${ }^{9}$

Pound mengatakan bahwa hukum kodrati dari setiap masa pada dasarnya berupa sebuah hukum kodrati yang "positif", versi ideal dari hukum positif pada masa dan tempat tertentu, "naturalisasi" untuk kepentingan kontrol sosial manakala kekuatan yang ditetapkan oleh masyarakat yang terorganisasi tidak lagi dianggap sebagai alat pembenar yang memadai. Ia mengakui kekaburan dari ketiga pengertian dari istilah hukum: hukum sebagai kaidah sosial, badan hukum sebagai badan yang otoritatif, serta hukum sebagai proses peradilan. Sehubungan dengan itu, Pound berusaha menyatukan ketiga pengertian tadi ke dalam sebuah definisi. Ia mendefinisikan hukum dengan fungsi utama dalam melakukan kontrol sosial: Hukum adalah suatu bentuk khusus dari kontrol sosial, dilaksanakan melalui badan khusus berdasarkan ajaran yang otoritatif, serta diterapkan dalam konteks dan proses hukum serta administrasi. ${ }^{10}$

Pound mengatakan bahwa kebutuhan akan adanya kontrol sosial bersumvbr dari fakta mengenai kelangkaan. Kelangkaan mendorong kebutuhan untuk menciptakan sebuah sistem hukum yang mampu mengklasifikasikan berbagai kepentingan serta menyahihkan sebagian dari kepentingan-kepentingan itu. Ia menyatakan bahwa hukum tidak melahirkan kepentingan, melainkan menemukannya dan menjamin keamanannya. Hukum memilih untuk berbagai kepentingan yang dibutuhkan untuk mempertahankan dan mengembangan peradaban. Pound mengakui adanya tumpang tindih dari berbagai kelompok kepentingan, yaitu antara kepentingan

${ }^{9}$ Ibid.

${ }^{10}$ Ibid., 75. 
individual atau personal dengan kepentingan publik atau sosial. Semua itu diamankan melalui dan ditetapkan dengan status "hak hukum".

Roscoe Pound memiliki pendapat mengenai hukum yang menitik beratkan hukum pada kedisiplinan dengan teorinya yaitu: "Law as a tool of social engineering" (bahwa hukum adalah alat untuk memperbaharui atau merekayasa masyarakat). Untuk dapat memenuhi peranannya, Roscoe Pound lalu membuat penggolongan atas kepentingan-kepentingan yang harus dilindungi oleh hukum itu sendiri, yaitu kepentingan umum (public interest), kepentingan masyarakat (social interest), dan kepentingan pribadi (private interest). Kepentingan umum (public interest) meliputi kepentingan negara sebagai badan hukum dan penjaga kepentingan masyarakat. Kepentingan masyarakat (social interest) meliputi kepentingan akan kedamaian dan ketertiban; perlindungan lembaga-lembaga sosial; pencegahan kemerosotan akhlak; pencegahan pelanggaran hak; dan kesejahteraan sosial. Kepentingan pribadi (private interest) meliputi pepentingan individu, keluarga, dan hak milik. ${ }^{11}$

Law as a tool of sosial engineering merupakan teori yang dikemukakan oleh Roscoe Pound, yang berarti hukum sebagai alat pembaharuan dalam masyarakat, dalam istilah ini hukum diharapkan dapat berperan merubah nilai-nilai sosial dalam masyarakat. Dengan disesuaikan dengan situasi dan kondisi di Indonesia, konsepsi "law as a tool of social engineering" yang merupakan inti pemikiran dari aliran pragmatic legal realism itu, oleh Mochtar Kusumaatmadja kemudian dikembangkan di Indonesia. Menurut pendapat Mochtar Kusumaatmadja ${ }^{12}$, konsepsi hukum sebagai sarana pembaharuan masyarakat Indonesia lebih luas jangkauan dan ruang lingkupnya daripada di Amerika Serikat tempat kelahirannya, alasannya oleh karena lebih menonjolnya perundangundangan dalam proses pembaharuan hukum di Indonesia (walau yurisprudensi memegang peranan pula) dan ditolaknya aplikasi mekanisme daripada konsepsi tersebut yang digambarkan akan mengakibatkan hasil yang sama daripada penerapan faham legisme yang banyak ditentang di Indonesia.

${ }^{11}$ Satjipto Raharjo, Ilmu Hukum (Bandung: Citra Aditya Bakti, 2006), 206.

${ }^{12}$ Mochtar Kusumaatmadja, Hukum, Masyarakat, dan Pembangunan (Bandung: Binacipta, 1990), 10. 
Sifat mekanisme itu nampak dengan digunakannya istilah "tool" oleh Roscoe Pound. Itulah sebabnya mengapa Mochtar Kusumaatmadja cenderung menggunakan istilah "sarana" daripada alat.

Disamping disesuaikan dengan situasi dan kondisi di Indonesia konsepsi tersebut dikaitkan pula dengan filsafat budaya dari Northrop ${ }^{13}$ dan policy-oriented dari Laswell dan Mc Dougal. Hukum yang digunakan sebagai sarana pembaharuan itu dapat berupa undang-undang atau yurisprudensi atau kombinasi keduanya, seperti telah dikemukakan dimuka, di Indonesia yang paling menonjol adalah perundang-undangan, yurisprudensi juga berperan namun tidak seberapa. Agar supaya dalam pelaksanaan perundang-undangan yang bertujuan untuk pembaharuan itu dapat berjalan sebagaimana mestinya, hendaknya perundang-undangan yang dibentuk itu sesuai dengan apa yang menjadi inti pemikiran aliran sociological Jurisprudence yaitu hukum yang baik hendaknya sesuai dengan hukum yang hidup didalam masyarakat. ${ }^{14}$ Sebab jika ternyata tidak, akibatnya ketentuan tersebut akan tidak dapat dilaksanakan dan akan mendapat tantangan-tantangan. Beberapa contoh perundangundangan yang berfungsi sebagai sarana pembaharuan dalam arti merubah sikap mental masyarakat tradisional kearah modern, misalnya larangan penggunaan koteka di Irian Jaya, keharusan pembuatan sertifikat tanah dan sebagainya. ${ }^{15}$

Dalam hal ini dengan adanya fungsi hukum sebagai sarana pembaharuan masyarakat, dapat pula diartikan, bahwa hukum digunakan sebagai alat oleh agent of change yang merupakan pelopor perubahan yaitu seseorang atau sekelompok orang yang mendapatkan kepercayaan masyarakat sebagai pemimpin dari satu atau lebih lembaga-lembaga kemasyarakatan. Pelopor ini melakukan penekanan untuk mengubah sistem sosial, ${ }^{16}$ mempengaruhi masyarakat dengan sistem yang direncanakan terlebih dahulu disebut social engineering ataupun planning atau sebagai alat rekayasa sosial.

${ }^{13}$ Ibid.

${ }^{14}$ Lili Rasjidi dan Ira Thania Rasjidi, Pengantar Filsafat Hukum (Bandung: Mandar Maju, 2002), 74.

${ }^{15} \mathrm{Ibid}$.

${ }^{16}$ AA N Gede Dirksen, Pengantar Ilmu Hukum, (Diktat Untuk Kalangan Sendiri Tidak Diperdagangkan, Fakultas Hukum Universitas Udayana, 2009) 89. 
Law as a tool of social engineering dapat pula diartikan sebagai sarana yang ditujukan untuk mengubah perilaku warga masyarakat, sesuai dengan tujuan-tujuan yang telah ditetapkan sebelumnya. ${ }^{17}$ Salah satu masalah yang dihadapi di dalam bidang ini adalah apabila terjadi apa yang dinamakan oleh Gunnar Myrdal sebagai softdevelopment yaitu dimana hukum-hukum tertentu yang dibentuk dan diterapkan ternyata tidak efektif. ${ }^{18}$ Gejala-gejala semacam itu akan timbul, apabila ada faktor-faktor tertentu yang menjadi halangan. Faktorfaktor tersebut dapat berasal dari pembentuk hukum, penegak hukum, para pencari keadilan, maupun golongan-golongan lain dalam masyarakat. Faktor-faktor itulah yang harus diidentifikasikan, karena suatu kelemahan yang terjadi kalau hanya tujuan-tujuan yang dirumuskan tanpa mempertimbangkan sarana-sarana untuk mencapai tujuan-tujuan tersebut. kalau hukum merupakan sarana yang dipilih untuk mencapai tujuan-tujuan tersebut maka prosesnya tidak hanya berhenti pada pemilihan hukum sebagai sarana saja tetapi pengetahuan yang mantap tentang sifat-sifat hukum juga perlu diketahui untuk agar tahu batas-batas di dalam penggunaan hukum sebagai sarana untuk mengubah ataupun mengatur perilaku warga masyarakat. Sebab sarana yang ada, membatasi pencapaian tujuan, sedangkan tujuan menentukan sarana-sarana mana yang tepat untuk dipergunakan.

Hukum di dalam masyarakat modern saat ini mempunyai ciri menonjol yaitu penggunaannya telah dilakukan secara sadar oleh masyarakatnya. Di sini hukum tidak hanya dipakai untuk mengukuhkan pola-pola kebiasaan dan tingkah laku yang terdapat dalam masyarakat, melainkan juga untuk mengarahkannya kepada tujuan-tujuan yang dikendaki, menghapuskan kebiasaan yang dipandangnya tidak sesuai lagi, menciptakan pola-pola kelakuan baru dan sebagainya. Inilah yang disebut sebagai pandangan modern tentang hukum itu yang menjurus kepada penggunaan hukum sebagai instrument yaitu law as a tool social engineering. ${ }^{19}$

Penggunaan secara sadar tadi yaitu penggunaan hukum sebagai sarana mengubah masyarakat atau sarana pembaharuan masyarakat

\footnotetext{
${ }^{17}$ Soerjono Soekanto, Pokok-Pokok Sosiologi Hukum (Jakarta: Rajawali Pers, 2009), 135.

${ }^{18} \mathrm{Ibid}$.

${ }^{19}$ Raharjo, Ilmu Hukum, 206.
} 
itu dapat pula disebut sebagai social engineering by the law. ${ }^{20}$ Langkah yang diambil dalam social engineering itu bersifat sistematis, dimulai dari identifikasi problem sampai kepada jalan pemecahannya, yaitu, pertama, mengenal problem yang dihadapi sebaik-baiknya. Termasuk di dalamnya mengenali dengan seksama masyarakat yang hendak menjadi sasaran dari penggarapannya tersebut. Kedua, memahami nilai-nilai yang ada dalam masyarakat, hal ini penting dalam hal social engineering itu hendak diterapkan pada masyarakat dengan sektor-sektor kehidupan majemuk, seperti tradisional, modern dan perencanaan. Pada tahap ini ditentukan nilai-nilai dari sektor mana yang dipilih. Ketiga, membuat hipotesa-hipotesa dan memilih mana yang paling layak untuk bisa dilaksanakan. Keempat, mengikuti jalannya penerapan hukum dan mengukur efek-efeknya.

\section{Teori Penegakan Hukum}

Roscoe Pound (1870-1964) dianggap sebagai pembentuk ilmu hukum sosiologis, disini sumbangsih pemikirannya merupakan bagaimana mengembangkan konsep-konsep baru untuk mempelajari hukum di dalam masyarakat. Timbul dan berkembangnya teknologi serta pengaruhnya terhadap kehidupan sosial dan ekonomis menimbulkan gagasan Pound untuk menjelaskan bahwa hukum adalah alat untuk mengubah atau merekayasa masyarakat ("law is a tool of social engineering). Akibat pemikiran dari Pound ini, di Indonesia muncul tokoh sosilogis hukum yang sangat disegani pemikirannya berkat penemuannya tentang hukum progresif, yaitu Prof. Dr. Satjipto Raharjo. Inti pemikiran dari kedua pemikir dalam mazhab sosiologi hukum adalah : Hukum yang baik adalah hukum yang sesuai dengan hukum yang hidup di masyarakat. ${ }^{21}$

Kaitannya dengan produk hukum yang ada di Indonesia yaitu, bahwa bagaimana produk hukum tersebut bisa membaur dengan kehidupan masyarakat, atau bagaimana hukum tetap menunjukkan superiornya di masyarakat sebagai alat untuk mengubah masyarakat, namun hukum tersebut juga tidak menimbulkan kesengsaraan di dalam masyarakat. Menyitir pendapat dari Satjipto Raharjo, bahwa

${ }^{20} \mathrm{Ibid}$.

${ }^{21}$ Satjipto Raharjo, Membedah Hukum Progresif (Jakarta: Kompas Media Nusantara. Cetakan III, 2008), 48. 
penerapan hukum yang ada di masyarakat tidak harus melihat produk hukumnya, tetapi bagaimana suatu produk tersebut bisa diartikan semaksimal mungkin dan dipraktekkan sesuai dengan kebutuhan masyarakat untuk mencapai keadilan.22

Dari pendapat di atas baik Pound maupun Satjipto beranggapan bahwa tujuan pembentukan hukum harus ditelaah dalam kerangka pencapaian batas-batas maksimal pemenuhan kebutuhan manusia. Oleh sebab itu, dalam pembentukan suatu produk hukum harus dirombak dengan cara menetapkan kerangka dasar lain yang memperhatikan pengakuan yang lebih luas terhdap kebutuhan, permintaan, maupun kepentingan sosial.

Hukum sebagai lembaga yang bekerja di dalam masyarakat minimal memiliki 3 (tiga) perspektif dari fungsinya (fungsi hukum), yaitu: ${ }^{23}$ Pertama, sebagai kontrol sosial dari hukum yang merupakan salah satu dari konsep-konsep yang biasanya, paling banyak digunakan dalam studi-studi kemasyarakatan. Dalam perspektif ini fungsi utama suatu sistem hukum bersifat integratif karena dimaksudkan untuk mengatur dan memelihara regulasi sosial dalam suatu sistem sosial. Oleh sebab itu dikatakan Bergers, ${ }^{24}$ bahwa tidak ada masyarakat yang bisa hidup langgeng tanpa kontrol sosial dari hukum sebagai sarananya. Selanjutnya menurut Parsons agar hukum dapat mengemban fungsi kontrol tersebut, mengemukakan ada 4 (empat) prasyarat fungsional dari suatu sistem hukum, yaitu masalah dasar legitimasi, yakni menyangkut ideologi yang menjadi dasar penataan aturan hukum; masalah hak dan kewajiban masyarakat yang menjadi sasaran regulasi hukum proses hukumnya; masalah sanksi dan lembaga yang menerapkan sanksi tersebut; dan masalah kewenangan penegakan aturan hukum. ${ }^{25}$

Kedua sebagai social engineering yang merupakan tinjauan yang paling banyak pergunakan oleh pejabat (the official perspective of the law) untuk menggali sumber-sumber kekuasaan apa yang

${ }^{22}$ Ibid.

${ }^{23}$ A. G. Peters dalam Ronny Hanitijo Soemitro, Study Hukum dan Masyarakat (Bandung: Alumni, 1998), 10.

${ }^{24}$ Peter L. Berger, Invitation to Sociologi: A Humanistic Prospective, Terj. Daniel Dhakidae (Jakarta: Inti Sarana Aksara,1992), 98.

${ }^{25}$ Tom Campbell, Tujuh Teori Sosial (Sketsa, Penilaian dan Perbandingan) (Yogyakarta: Kanisius, 1994), 220-230. 
dapat dimobilisasikan dengan menggunakan hukum sebagai mekanismenya. Mengikuti pandangan penganjur perspective social engineering by the law, oleh Satjipto Rahardjo, ${ }^{26}$ dikemukakan adanya 4 (empat) syarat utama yang harus dipenuhi agar suatu aturan hukum dapat mengarahkan suatu masyarakat, yaitu dengan cara penggambaran yang baik dari suatu situasi yang dihadapi; analisa terhadap penilaian-penilaian dan menentukan jenjang nilai-nilai; verifikasi dari hipotesis-hipotesis; dan adanya pengukuran terhadap efektivitas dari undang-undang yang berlaku.

Ketiga perspektif emansipasi masyarakat terhadap hukum. Perspektif ini merupakan tinjauan dari bawah terhadap hukum (the bottoms up view of the law), hukum dalam perspektif ini meliputi obyek studi seperti misalnya kemampuan hukum, kesadaran hukum, penegakan hukum dan lain sebagainya.

Masalah penegakan hukum adalah merupakan suatu persoalan yang dihadapi oleh setiap masyarakat. Walaupun kemudian setiap masyarakat dengan karakteristiknya masing-masing, mungkin memberikan corak permasalahannya tersendiri di dalam kerangka penegakan hukumnya. Namun setiap masyarakat mempunyai tujuan yang sama, agar di dalam masyarakat tercapai kedamaian sebagai akibat dari penegakan hukum yang formil.

Tugas utama hukum adalah rekayasa sosial (law as a tool of social engineering, Roscoe Pound). Hukum tidak saja dibentuk berdasarkan kepentingan masyarakat tetapi juga harus ditegakkan sedemikian rupa oleh para yuris sebagai upaya sosial kontrol dalam arti luas yang pelaksanaannya diorientasikan kepada perubahan-perubahan yang dikehendaki. $^{27}$

Oleh karena itu, sangat dipengaruhi oleh komponen-komponen di luar hukum, maka para penegak hukum dalam mewujudkan tugas utama hukum harus memahami secara benar logika, sejarah, adat, istiadat, pedoman prilaku yang benar agar keadilan dapat ditegakkan. Keputusan hukum yang adil dapat digunakan sebagai sarana untuk mengembangkan masyarakat. Tugas utama adalah sarana pembaharuan masyarakat dalam pembangunan.

${ }^{26}$ Satjipto Rahardjo. Pemanfaatan Ilmu Sosial Bagi Pengembangan Ilmu Hukum (Bandung: Alumni, 1977), 66.

${ }^{27}$ Ibid., 67. 
Kehidupan hukum sebagai kontrol sosial terletak pada praktek pelaksanaan atau penerapan hukum tersebut. Tugas hakim dalam menerapkan hukum tidak melulu dipahami sebagai upaya social control yang bersifat formal dalam menyelesaikan konflik, tetapi sekaligus mendesain penerapan hukum itu sebagai upaya social engineering. Tugas yudisial hakim tidak lagi dipahami sekedar sebagai penerap undang-undang terhadap peristiwa konkrit (berupa berbagai kasus dan konflik) atau sebagai sekedar corong undang-undang (boncha de la loi) tetapi juga sebagai penggerak social engineering. Para penyelenggara hukum harus memperhatikan aspek fungsional dari hukum yakni untuk mencapai perubahan, dengan melakukan perubahan hukum selalu dengan menggunakan segala macam teknik penafsiran (teori hukum fungsional).

"Law is a tool of social engineering" adalah apa yang dikatakan oleh Roscoe Pound terhadap hukum itu. Sama seperti apa yang dikatakan oleh Mochtar Kusumaatmadja, hukum adalah keseluruhan azasazas dan kaedah-kaedah yang mengatur masyarakat, termasuk di dalamnya lembaga dan proses untuk mewujudkan hukum itu ke dalam kenyataan. Kedua ahli hukum ini memiliki pandangan yang sama terhadap hukum. ${ }^{28}$

Kepentingan negara adalah harus yang paling tinggi/atas dikarenakan negara mempunyai kepentingan nasional. Kepentingan nasional tersebut harus melindungi kepentingan negara kemauan negara adalah kemauan publik. Karena hukum itu bukan seperti yang dikatakan oleh teori-teori positivis menghukum bahwa hukum memiliki sifat tertutup. Hukum sangat dipengaruhi oleh ideologi, politik, ekonomi, sosial, budaya. Tidak hanya sekedar kemauan pemerintan. Suatu logika yang terbuka, perkembangan kebutuhan masyarakat sangat mempengaruhi pertumbuhan hukum di dalam masyarakat. Politik sangat mempengaruhi pertumbuhan hukum di dalam masyarakat. ${ }^{29}$

Salah satu masalah yang dihadapi adalah menemukan sistem dan pelaksanaan penegakan hukum yang dapat menjelmakan fungsi hukum dengan baik seperti fungsi kontrol sosial, fungsi menyelesaikan perselisihan, fungsi memadukan, fungsi memudahkan, fungsi

${ }^{28} \mathrm{Ibid}$.

${ }^{29} \mathrm{Ibid}$., 68. 
pembaharuan, fungsi kesejahteraan dan lain-lain. Pada saat ini, perbedaan-perbedaan fungsi hukum tersebut, sering kali menjadi unsur yang mendorong timbulnya perbedaan mengenai tujuan menerapkan hukum. Ada yang lebih menekankan pada fungsi kontrol sosial, atau fungsi perubahan, dan lain-lain. Kalau masing-masing pihak menuntut menurut keinginannya sendiri-sendiri maka yang timbul adalah permasalahan hukum bukan penyelesaian hukum. Bahkan menimbulkan konflik yang berkonotasi saling menyalahkan, saling menuduh, dan lain-lain. Fungsi utama hukum adalah untuk melindungi kepentingan yang ada dalam masyarakat. Seperti yang dibahas pada topik sebelumnya dalam konteks kepentingan menurut Roscoe Pound. Rincian dari tiap-tiap kepentingan tersebut bukan merupakan daftar yang mutlak tetapi berubah-ubah sesuai dengan perkembangan masyarakat. Jadi, sangat dipengaruhi oleh waktu dan kondisi masyarakat.Apabila susunan kepentingan-kepentingan tersebut disusun sebagai susunan yang tidak berubah-ubah, maka susunan tersebut bukan lagi sebagai social engineering tetapi merupakan pernyataan politik (manifesto politik).

\section{Pendekatan Hukum Islam berdasarkan Teori Law is A Tool of Social Engineering agar Dapat Menjadi Kontrol Sosial bagi Pelaku Tindak Pidana Korupsi}

Bila melihat ketiga perspektif dalam teori Law as a tool of sosial engineering, maka hukum Islam dapat digunakan sebagai salah satu bentuk aturan yang diberlakukan di Indonesia ke dalam pembentukan peraturan perundang-undangan korupsi untuk memberikan sanksi bagi pelaku tindak pidana korupsi. Ada beberapa alasan yang melandasi hal tersebut seperti yang dijelaskan di wah ini.

Pertama, hukum Islam sebagai kontrol sosial yang merupakan salah satu dari konsep-konsep yang biasanya paling banyak digunakan dalam studi-studi kemasyarakatan, karena masyarakat Indonesia mayoritas adalah agama Islam. Dalam perspektif ini fungsi utama dari hukum Islam secara integratif dimaksudkan untuk mengatur dan memelihara regulasi sosial masyarakat Indonesia yang sebagian besar umat muslim dalam suatu sistem hukum yang teregulasi dengan baik. Dalam hal ini adalah penggabungan hukum Islam dalam hukum positif di Indonesia yaitu terhadap tindak pidana korupsi. Contohnya: 
dalam fiqh dengan dianalogikan dengan perampokan, yaitu korupsi dilakukan dengan kekuatan dan kekuasaan dan yang telah dikorupsi telah mencapai satu nishab / batas minimal maka dikenakan dengan hukum potong tangan secara bersilangan sebatas pergelangan tangan. (Nishabnya seberat emas 93,6 gram, tahun 2011 emas 1 gram seharga Rp400.000,00 maka nishabnya $=$ Rp38.520.000,00). Sedangkan bagi pelaku yang telah berulang melakukan tindak pidana korupsi, maka berdasarkan Ijtima' Nahdlatul Ulama (NU) maka para koruptor boleh dihukum mati jika telah melakukan korupsi secara berulang-ulang. Dan dalam Undang-Undang Nomor 31 Tahun 1999 jo. Undang - Undang Nomor 20 Tahun 2001 Tentang Tindak Pidana Korupsi, hukuman maksimal yang dijatuhkan adalah 20 tahun penjara.

Kedua, hukum Islam sebagai sebagai social engineering yang merupakan tinjauan bisa dipergunakan oleh pejabat (the official perspective of the law) untuk menggali sumber-sumber kekuasaan apa yang dapat dimobilisasikan dengan menggunakan hukum Islam sebagai mekanismenya. Hal ini dikarenakan tindak pidana korupsi di Indonesia sudah sangat parah sekali dan hukuman yang diterima oleh si pelaku tindak pidana korupsi di Indonesia juga masih sangat ringan sekali. Memang tindak pidana korupsi merupakan suatu tindak pidana yang walaupun aturan perundang-undangannya yang bersifat tegas dan memaksa sudah ada, namun faktanya sampai kapanpun tindak pidana korupsi akan selalu ada. Maka disini peran pejabat pemerintah, baik sebagai pembuat kebijakan maupun sebagai aparat pengawas dan regulasi suatu produk hukum harus membuat suatu kebijakan atau peraturan perundang-undangan yang nantinya bisa menjadi social engineering bagi seluruh masyarakat di Indonesia. Salah satunya adalah dalam pembuatan produk perundang-undangan itu sendiri, maka perlu memperhatikan juga sumber-sumber hukum yang hidup di masyarakat, salah satunya adalah hukum Islam. Berkaitan dengan tindak pidana korupsi yang terjadi di Indonesia, walaupun dalam aturan Undang-Undang Korupsi ada pasal tentang hukuman mati, namun faktanya dalam penerapan sanksinya tidak ada hukuman mati. Kenapa perlu juga ada sanksi hukuman mati? Karena tindak pidana korupsi juga merupakan bentuk kejahatan exstra ordinary crime, atau dikenal sebagai tindak pidana luar biasa, 
sama seperti terorisme dan narkoba. Ijtima' Nahdlatul Ulama (NU) yang pernah mengeluarkan fatwa bolehnya hukuman mati bagi koruptor. Menurut fatwa tersebut, para koruptor boleh dihukum mati jika telah melakukan korupsi secara berulang-ulang. Wahbah Zuhaili dalam Al-Fiqh al-Islami wa Adillatuh menyimpulkan, hukuman mati boleh saja diberikan kepada orang yang sudah sangat sering melakukan tindakan kriminal, pecandu minuman keras (apalagi narkoba), para penganjur tindak kejahatan, dan pelaku tindakan subversif yang mengancam keamanan negara atau semisalnya. Koruptor bisa termasuk kategori jenis ini. ${ }^{30}$ Dari fatwa dan pandangan ahli fiqih tersebut, bisa diterapkan dalam peraturan perundang-undangan di Indonesia, agar penerapan sanksi tindak pidana korupsi bagi mereka yang melakukan tindak pidana korupsi berulang-ulang (resedivis) bisa dijatuhi dengan maksimal hukuman mati. Sama halnya dengan tindak pidana korupsi yang dilakukan secara bersama-sama (korporasi) bagi mereka yang memang terbukti melakukan persekongkolan jahat dengan bersama-sama mengakibatkan kerugian Negara, maka juga bisa diberikan hukuman yang berat bahkan hukuman mati sesuai dengan al-Qur'an, al-hadits dan 'Ijma serta fatwa dari ulama-ulama fiqiyah.

Ketiga, perspektif emansipasi masyarakat Islam di Indonesia terhadap hukum (budaya hukum). Perspektif ini merupakan tinjauan dari bawah terhadap hukum (the bottoms up view of the law), hukum dalam perspektif ini meliputi obyek studi seperti misalnya kemampuan hukum, kesadaran hukum, penegakan hukum dan lain sebagainya. Masyarakat Indonesia sudah sangat menderita dengan banyaknya kasus-kasus korupsi yang selalu berulang dan terjadi terus menerus di Indonesia, bahkan kasus korupsi juga telah membudaya ditingkat pemerintahan terkecilpun di Indonesia. Disini perspektif dari masyarakat Islam yang ada di Indonesia, juga perlu dperhatikan oleh Pemerintah. Masyarakat Islam di Indonesia sudah tidak percaya lagi dengan pejabat pemerintah. Contohnya dalam pengurusan E-KTP masyarakat di desa, yang berdasarkan peraturan presiden, pengurusan E-KTP gratis, faktanya banyak pejabat pemerintahan desa yang melakukan pungutan liar terhadap masyarakatnya. Belum di pemerintahan pusat, terjadinya indikasi kebocoran dana

${ }^{30}$ Ibid.

Kodifikasia, Volume 11 No. 1 Tahun 2017 
pembuatan E-KTP yang dicanangkan secara nasional, ternyata juga disalahgunakan untuk kepentingan pribadi maupun kelompok. Terjadinya penyelewengan uang Negara dalam proyek E-KTP sampai saat ini masih disidik oleh pihak KPK. Apabila mengacu dari contoh kasus tersebut, pandangan masyarakat di Indonesia, khususnya umat muslim setuju apabila pelaku tindak pidana korupsi juga bisa diberikn hukuman potong tangan. ${ }^{31} \mathrm{Hal}$ ini karena korupsi bisa diqiyaskan dengan tindak pidana pencurian dalam Islam, yang diatur dalam Al-Qur'an. Namun dalam konsepsi hukum Islam sangat sulit untuk mengkategorikan tindak pidana korupsi sebagai delik sirqah (pencurian). Hal ini disebabkan oleh beragamnya praktek korupsi itu sendiri yang umumnya tidak masuk dalam definisi sariqah (pencurian). Namun jika dalam satu kasus tindak pidana korupsi telah sesuai dengan sariqah, menurut Alatas, ${ }^{32}$ korupsi mengandung dua unsur penting yaitu penipuan dan pencurian. Apabila bentuknya pemerasan itu berarti pencurian melalui pemaksaan terhadap korban. Apabila penyuapan terhadap pejabat itu berarti membantu terjadinya pencurian. Jika terjadi dalam penentuan kontrak atau suatu proyek dipemerintahan,maka korupsi ini berarti pencurian keputusan sekaligus pencurian hasil keputusan. Jadi kalau unsureunsur sariqah telah terpenuhi dalam tindak pidana korupsi maka pelakunya dikenakan potong tangan. Sayyid Sabiq dalam kitabnya Fiqhus Sunnah, ${ }^{33}$ dengan lugas mengkategorikan bahwa jika seseoran mengambil harta yang bukan miliknya secara sembunyi-sembunyi dari tempatnya (hirz mitsl) maka itu dikategorikan pencurian, jika iya mengambilnya secara paksa dan terang-terangan, maka dinamakan

${ }^{31} \mathrm{Hal}$ ini berdasarkan atas hasil penelitian yang dilakukan oleh Siti Khodijah, dalam skripsi yang berjudul "Hukum Potong Tangan dan Pemberlakuannya Di Indonesia (Studi atas Pandangan Ulama Muhammadiyah dan NU)", UIN Syarif Hidayatullah Jakarta, 2015. Menurut ulama Muhammadiyah dan NU, hukuman tangan adalah hukuman hudud yang telah ditetapkan oleh Allah untuk tindak pidana pencurian yang tertulis dalam Qs. Al-Maidah ayat 38. Ulama Muhammadiyah dan NU menyetujui hukuman potong tangan diberlakukan di Indonesia, karena hal ini dapat mengurangi tindak kejahatan terutama pencurian, termasuk dalam hal ini juga tindak pidana korupsi.Karena menurut Muhammadiyah dan NU, hukuman potong tangan jika diberlakukan di Indonesia juga tidak bertentangan dengan konstitusi. Karena menurut ulama Muhammadiyah dan NU, hukuman potong tangan jauh lebih efektif memberikan efek jera yang dapat dirasakan pelaku maupun orang lain yang akan berbuat tindak pidan yang sama.

${ }^{32}$ Andsbarcaboy.blokspot.co.id. Korupsi Dalam Pandangan Islam, 19 Maret 2013.

${ }^{33}$ Tafsir Ibnu Katsir, Imam Ibnu Katsir. 
merampok (muharabah), jika iya mengambil tanpa hak dan lari maka dinamakan mwncopet (ikhtilas), dan apabila iya mengambil sesuati yang dipercayakan padanya, dinamakan khiyanah. Namun mayoritas ulama syafi'iyyah lebih cenderung mengkategorikan korupsi sebagai penghianatan, karena pelakunya adalah orang yang dipercayakan untuk mengelola harta dari Negara. Sehingga bisa diterapakan juga hukuman penjara, bahkan dipenjara sampai mati. Jenis-jenis hukuman khianat yang dapat diberlakukan bagi pelaku korupsi dalam hukum Islam, menurut Imam asy Syafi'I, adalah: ${ }^{34}$ penjara, pukulan yang tidak menyebabkan luka, menampar, dipermalukan (dengan kata-kata atau mencukur rambutnya), diasingkan, dan hukuman cambuk di bawah empat puluh kali. Khusus untuk hukuman penjara terhadap pelaku khianat yang banyak memudharatkan orang lain dengan penjara sampai mati (seumur hidup). ${ }^{35}$

\section{Teori Law Is A Tool of Social Engineering Penerapan Undang- Undang Korupsi di Indonesia}

Sebagai kejahatan yang membahayakan kehidupan sosial, korupsi selalu dikaitkan dengan budaya atau kondisi sosial masyarakat. Menurut Robert Klitgaard, penyebab utama korupsi adalah pemberian hadiah yang sudah merupakan adat istiadat. Seiring dengan pendapat tersebut, Umi Kulsum berpendapat bahwa tindak pidana korupsi di Indonesia merupakan perbuatan yang telah mengakar dalam berbagai sendi kehidupan manusia, sehingga seolah-olah dianggap sebagai budaya. ${ }^{36}$

Istilah hadiah yang kemudian berkembang menjadi suap (seolah membudaya) merupakan hal yang sangat berbahaya bagi perkembangan korupsi selanjutnya, sehingga kemudian ada sebuah adagium "kalau seorang diduga melakukan korupsi dan kemudian diperiksa oleh penegak hukum maka penegak hukum sudah memulai korupsi pada saat pemeriksaan dilakukan, karena pada pemeriksaan itulah terjadi suap terhadap pemeriksa. ${ }^{37}$

${ }^{34}$ Shahih Al-Bukhari dan Shahih Muslim.

${ }^{35}$ Teungku H. Hasanoel Bashry, Korupsi dalam Tinjauan Fiqih Jinayati (Bandung: Pelita, 2009), 112.

${ }^{36}$ Umi Kulsum, "Kewenangan Komisi Pemberantasan Korupsi (KPK) dalam Melakukan Pemberantasan Tindak Pidana Korupsi" Jurnal Jure Humano, Volume 1, Nomor 3, 2009:81.

${ }^{37}$ Satjipto Rahardjo, Membangun dan Merombak Hukum Indonesia, Sebuah Pendekatan Lintas Disiplin (Yogyakarta: Genta Publishing, 2009), 6.

Kodifikasia, Volume 11 No. 1 Tahun 2017 
Hal ini ditengarai sebagai suatu budaya yang tumbuh akibat mental-mental pejabat negara yang tidak baik. Kondisi tersebut tentu bukan tanpa alasan, karena menurut Koentjoroningrat, salah satu ciri mental manusia Indonesia adalah sikap untuk mencapai tujuan secepatnya, tanpa banyak kerelaan untuk berusaha secara selangkah demi selangkah. ${ }^{38}$ Sikap mental inilah yang kemudian mendorong para penyelenggara negara atau tepatnya penegak hukum untuk melakukan tindakan tidak terpuji yaitu suap. Yang kemudian melahirkan istlah kejahatan kerah putih. Namun demikian, faktor budaya yang disinyalir sebagai penyebab korupsi ini tidaklah tepat, karena menurut Francis Fukuyama pengaruh budaya"inherited ethical habit" (kebiasaan baik yang diturunkan turun temurun). ${ }^{39}$ Sehingga menurut Francis Fukuyama tersebut menunjukkan bahwa korupsi sebagai perilaku jahat bukanlah sebuah budaya bahkan dapat dikatakan bahwa korupsi pada hakikatnya merupakan tindakan anti budaya (anti kebiasaan baik yang seharusnya menjadi perilaku yang dapat diwariskan secara turun temurun). ${ }^{40}$

Sebagai sebuah kejahatan, pada hakikatnya korupsi dihasilkan dari sebuah proses pembelajaran, menurut Sutherland, melalui teorinya yang terkenal yaitu teori differential association yang menegaskan bahwa suatu kejahatan (termasuk korupsi atau dalam bahasanya White collar Crime) merupakan kejahatan yang diperolehnya dengan cara dipelajari, dengan sembilan proposisi. Pertama, criminal behavior is learned. Negatively, this means that criminal behavior is not inherited. (perilaku kejahatan adalah perilaku yang dipelajari secara negatif berarti perilaku ini tidak diwarisi). Kedua, criminal behavior is learned in interaction with other persons in a process of Communications. This comunication is verbal in many respects but includes also "the comunication of gesture." (perilaku kejahatan dipelajari dalam interaksi dengan orang lain dalam suatu proses komunikasi. komunikasi tersebut terutama dapat bersifat lisan ataupun menggunakan bahasa isyarat). Ketiga, the principle part of the learning of criminal behavior occurs within intimate personal groups.

${ }^{38}$ Benny S. Tabalujan, Legal Development in Development Countries-The Role of Legal Culture" (Singapore, 2001), 27.

${ }^{39}$ Ibid.

${ }^{40}$ Ridwan, Kebijakan Formulasi Hukum Pidana Dalam Penanggulangan Tindak Pidana Korupsi (Tesis, UNDIP, 2010) 71.

Kodifikasia, Volume 11 No. 1 Tahun 2017 
Negatively, this means that the interpersonal agencies of Communications, such as movies, and newspaper, plays a relatively unimportant in the genesis of criminal behavior. (bagian yang terpenting dalam proses mempelajari perilaku kejahatan ini terjadi dalam kelompok personal yang intim. Secara negatif, hal ini berarti komunikasi yang bersifat tidak personal, secara relatif tidak mempunyai peranan penting dalam hal terjadinya kejahatan). Keempat, when criminal behavior is learned, the learning includes (a) techniques of committing the Crime, which are sometimes very complicated, sometimes very simple.( $b$ ) the specific direction of motives, Drive, rationalizations and attitudes. (apabila perlilaku kejahatan dipelajari maka yang dipelajari meliputi (a) teknik melakukan kejahatan, (b) motif-motif tertentu, dorongandorongan, alasan-alasan pembenar termasuk sikap-sikap). Kelima, The specific direction of motives and Drive is learned from definitions of the legal codes as favorable on unfavorable. In some societies an individual is surrounded by person who invariably define the legal codes as rules to be observed, while in others he is surrounded by person whose definitions are favorable to the violation of the legal codes. (arah motif dan dorongan itu dipelajari melalui definisi-definisi dari peraturan hukum. Dalam suatu masyarakat kadang seseorang dikelilingi oleh orang-orang yang secara bersamaan melihat apa yang diatur dalam peraturan hukum sebagai sesuatu yang perlu diperhatikan dan dipatuhi, namun kadang ia dikelilingi orang-orang yang melihat aturan hukum sebagai sesuatu yang memberi peluang dilakukannya kejahatan). Keenam, A persons becomes delinquent because of an excess of definitions favorable to violation of law over definitions unfavorable to violation of law. (seseorang menjadi delinkuen karena akses dari pola-pola pikir yang lebi hmelihat aturan hukum sebagai pemberi peluang untuk dilakukan kejahatan daripada yang melihat hukum sebagai sesuatu yang harus diperhatikan dan dipatuhi). Ketujuh, Differential Association may vary in frequency, duration, priority, and intensity. (Differential Association bervariasi dalam hal frekuensi, jangka waktu, prioritas, serta insensitasnya). Kedelapan, The process of learning criminal behavior by association with criminal and anticriminal patterns in volves all of the mechanisms that are involved in any other learning. (proses mempelajari perilaku kejahatan yang diperoleh melalui hubungan dengan pola-pola kejahatan dan antikejahatan yang menyangkut seluruh mekanisme yang lazimnya 
terjadi dalam setiap proses belajar pada umumnya). Kesembila, While criminal behavior is an expression of general needs and values, it is not explained by those general needs and values since criminal noncriminal behavior is an expression of the same needs and values. (sementara itu perilaku kejahatan merupakan pernyataan kebutuhan dan nilai umum, namun hal tersebut tidak dijelaskan oleh kebutuhan dan nilai umum itu, karena perilaku yang bukan kejahatan juga merupakan pernyataan dari kebutuhan-kebutuhan dan nilai-nilai yang sama). ${ }^{41}$

Untuk menangkal kejahatan korupsi sebagai kejahatan yang berbahaya bagi kehidupan sosial, diperlukan sebuah perubahan kultur (sosial engineering) atau alat rekayasa sosial, namun demikian perubahan kultur merupakan perubahan yang sangat besar dan bukan pekerjaan yang mudah, bahkan menurut Satjipto Rahardjo perubahan tersebut membutuhkan pengkajian dan penelitian yang seksama. ${ }^{42}$ Namun demikian perubahan tersebut dapat dilakukan pula melalui sebuah perubahan atau penataan kembali pada sistem hukum pidana yang mengatur mengenai tindak pidana korupsi, yang diharapkan mampu mempengaruhi sikap tindak bangsa Indonesia tanpa kecuali.

Perubahan kultur melalui penataan hukum tersebut oleh Soerjono Soekanto dinamakan sebagai social engineering atau social planing yaitu cara-cara untuk mempengaruhi masyarakat dengan sistem yang teratur dan direncanakan terlebih dahulu. ${ }^{43}$ Social engineering tersebut erat kaitannya dengan fungsi undang-undang yaitu kepastian dan penegakan hukum Menurut D. Schaffmeister bahwa undang-undang mempunyai fungsi penciptaan jikalau norma hukum itu menyimpang dari norma sosial dan dengan demikian manusia akan berprilaku lain daripada semula. ${ }^{44}$ Untuk menciptakan perubahan sosial melalui penataan sistem hukum, maka diperlukan social engineering yang baik, di mana hukum yang akan digunakan harus benar-benar mencerminkan perlindungan terhadap

${ }^{41}$ Paulus Hadisuprapto, Deliquensi Anak Pemahaman dan Penanggulangannya (Malang: Bayumedia Publishing, 2008), 24-26.

${ }^{42}$ Satjipto Rahardjo, Hukum Progresif, Sebuah Sintesa Hukum Indonesia (Yogyakarta: Genta Publishing, 2009), 46.

${ }^{43}$ Soerjono Soekanto, Pokok-pokok Sosiologi Hukum, 107.

${ }^{44}$ D.Schaffmeister, et.al, Hukum Pidana, Terj. J.E.Sahetapy (Yogyakarta: Liberty. 1995), 22. 
kepentingan publik. ${ }^{45}$ Sebagai gambaran, menurut Andi Hamzah bahwa di Australia perumusan delik korupsi lebih menitik beratkan pada kepentingan publik, jadi publiklah yang selalu didahulukan dan dimenangkan. ${ }^{46}$ Untuk itulah maka diperlukan upaya-upaya melalui penal policy.

Penal policy merupakan suatu ilmu yang harus dimiliki oleh para pembaharu dan pelaksana hukum. Menurut Marc Ancel, penal policy adalah suatu ilmu sekaligus seni yang pada akhirnya mempunyai tujuan praktis untuk memungkinkan peraturan hukum positif dirumuskan secara lebih baik dan untuk memberi pedoman tidak hanya kepada pembuat undang-undang, tetapi juga kepada pengadilan yang menerapkan undang-undang dan juga kepada para penyelenggara atau pelaksana putusan pengadilan.

Searah dengan pendapat A. Mulder tersebut, maka Sudarto merumuskan Politik hukum sebagai usaha untuk mewujudkan peraturan-peraturan yang baik sesuai dengan keadaan dan situasi pada suatu waktu. ${ }^{47}$ Hal ini juga ditegaskan oleh Barda Nawawi Arief bahwa, mempelajari kebijakan hukum pidana pada dasarnya mempelajari masalah bagaimana sebaiknya hukum pidana itu dibuat, di susun dan digunakan untuk mengatur/mengendalikan tingkah laku manusia, khususnya untuk menanggulangi kejahatan dalam rangka melindungi dan menyejahterakan masyarakat. ${ }^{48}$

Berkaitan dengan perubahan atau pembaharuan hukum yang bertujuan menyejahterakan masyarakat (yaitu hukum sebagai rekayasa sosial atau law is a tool fo social engineering) tidaklah terlepas dari upaya kriminalisasi yaitu proses penetapan suatu perbuatan orang sebagai perbuatan yang dapat dipidana. Proses ini diakhiri dengan terbentuknya undang-undang di mana perbuatan itu diancam dengan suatu sanksi yang berupa pidana. ${ }^{49}$ Kriminalisasi tersebut menurut Sudarto harus memiliki empat kriteria. Pertama, penggunaan

${ }^{45}$ Ridwan, Kebijakan Formulasi Hukum Pidana Dalam Penanggulangan Tindak Pidana Korupsi, 75 .

${ }^{46}$ Andi Hamzah, Perbandingan Pemberantasan Korupsi di Berbagai Negara (Jakarta: Sinar Grafika, 2005), 12.

${ }^{47}$ Sudarto, Hukum dan Hukum Pidana (Bandung: Alumni, 1977), 159.

${ }^{48}$ Barda Nawawi Arief, Beberapa Aspek Pengembangan Ilmu Hukum Pidana (Menyongsong Generasi Baru Hukum Pidana Indonesia) (Semarang: Badan Penerbit Undip. 2007), 7-8.

${ }^{49}$ Sudarto, Hukum dan Hukum Pidana, 39. 
hukum pidana harus memperhatikan tujuan pembangunan nasional yaitu mewujudkan masyarakat adil makmur yang merata materiil dan spiritual berdasarkan Pancasila; sehubungan dengan ini maka (penggunaan) hukum pidana bertujuan untuk menanggulangi kejahatan dan mengadakan pengugeran terhadap tindakan penanggulangan itu sendiri, demi kesejahteraan dan pengayoman masyarakat. Kedua, perbuatan yang diusahakan untuk dicegah atau ditanggulangi dengan hukum pidana harus merupakan "perbuatan yang tidak dikehendaki" yaitu perbuatan yang mendatangkan kerugian (materiil dan atau spiritual) atas warga masyarakat. Ketiga, penggunaan hukum pidana haru pula memperhitungkan prinsip "biaya dan hasil". Keempat, penggunaan hukum pidana harus pula memperhatikan kapasitas dan kemampuan daya kerja dari badanbadan penegak hukum, yaitu jangan sampai ada kelampauan beban tugas. ${ }^{50}$

Jadi, dengan demikian tujuan akhir dari pembaharuan hukum adalah untuk menanggulangi kejahatan dan kesejahteraan masyarakat, untuk itulah penempatan kepentingan publik atau kepentingan masyarakat harus menjadi prioritas utama, dengan penal policy sebagai upaya mewujudka social engineering yang merupakan ilmu dan seni maka akan terjadi "penghalusan hukum" yang menurut Scholten penghalusan hukum tersebut bertujuan untuk menggunakan ketentuan yang bersifat umum secara lebih tepat dan adil. ${ }^{51}$ Apalagi persoalan korupsi sangat berdampak pada kepentingan ekonomi masyarakat, maka keadilan merupakan hal yang harus diwujudkan demi kepentingan masyarakat atau publik. Sejalan dengan hal ini, Baharudin Lopa menyatakan bahwa, mencegah kolusi dan korupsi tidak begitu sulit, kalau kita secara sadar untuk menempatkan kepentingan umum di atas kepentingan pribadi dan golongan..$^{52} \mathrm{Jadi}$ hukum memaksa (rekayasa sosial) masyarakat dan penegak hukum untuk menempatkan bahwa kepentingan umum lebih tinggi dari kepentingan pribadi dan golongan. Oleh karena social angeneering itu untuk kepentingan publik, maka seharusnya penegakan hukum

${ }^{50}$ Muladi dan Barda Nawawi Arief, Teori-teori dan Kebijakan Pidana (Bandung: Alumni, 1998), 161.

${ }^{51}$ Satjipto Rahardjo, Hukum dan Perilaku (Jakarta: Kompas, 2009), 15.

${ }^{52}$ R. Diyatmiko Soemodihardjo, Mencegah dan Memberantas Korupsi, Mencermati Dinamikanya di Indonesia (Jakarta: Prestasi Pustaka Publisher, 2008), 12. 
itu harus merupakan pekerjaan yang terus menerus dilakukan dan dikoordinasikan antara pembuat kebijakan, penegak hukum dan masyarakat itu sendiri.

Jerome Hall berpendapat bahwa perbaikan/pembaharuan atau pengembangan hukum pidana sebagai kontrol sosial di masyarakat harus merupakan suatu usaha permanen yang terus menerus dan berbagai catatan/dokumen rinci mengenai hal itu seharusnya disimpan dan dipelihara. Penataan hukum yang baik melalui penal policy atau politik hukum dengan memperhatikan kriteria-kriteria dalam melakukan kriminalisasi sebagaimana diuraikan di atas, diharapkan tidak lagi terjadi ketimpangan-ketimpangan sosial, yang dapat menciptakan kondisi yang kondusif bagi suatu kejahatan terutama korupsi, yang merupakan kejahatan yang membahayakan kehidupan sosial. ${ }^{53}$

Agar social engineering terhadap Undang-Undang Pencegahan Tindak Pidan Korupsi berjalan sesuai dengan landasan keadilan sosial, maka perlu ada perubahan-perubahan terhadap rumusan tindak pidana mengenai korupsi sebagaimana yang diatur dalam UndangUndang Nomor 31 Tahun 1999 jo. Undang-Undang 20 Tahun 2001 sepanjang memenuhi kebutuhan masyarakat dan bertujuan untuk menciptakan kesejahteraan masyarakat atau kesejahteraan umum. Pada hakikatnya kesejahteraan umum akan mudah dicapai apabila prilaku-prilaku koruptif dapat dicegah melalui penataan hukum yang lebih baik (penal policy).

\section{PENUTUP}

Bila melihat ketiga perspektif dalam teori Law as a tool of sosial engineering, maka hukum Islam dapat digunakan sebagai salah satu bentuk aturan yang diberlakukan di Indonesia ke dalam pembentukan peraturan perundang-undangan korupsi untuk memberikan sanksi bagi pelaku tindak pidana korupsi. Alasannya karena beberapa hal. Pertama, hukum Islam sebagai kontrol sosial yang merupakan salah satu dari konsep-konsep yang biasanya paling banyak digunakan dalam studi-studi kemasyarakatan, karena masyarakat Indonesia mayoritas adalah agama Islam. Dalam perspektif ini fungsi utama

${ }^{53}$ Ridwan, Kebijakan Formulasi Hukum Pidana Dalam Penanggulangan Tindak Pidana Korupsi, 79

Kodifikasia, Volume 11 No. 1 Tahun 2017 
dari hukum Islam secara integratif dimaksudkan untuk mengatur dan memelihara regulasi sosial masyarakat Indonesia yang sebagian besar umat muslim dalam suatu sistem hukum yang teregulasi dengan baik. Kedua, hukum Islam sebagai sebagai social engineering yang merupakan tinjauan bisa dipergunakan oleh pejabat (the official perspective of the law) untuk menggali sumber-sumber kekuasaan apa yang dapat dimobilisasikan dengan menggunakan hukum Islam sebagai mekanismenya. Ketiga, perspektif emansipasi masyarakat Islam di Indonesia terhadap hukum (budaya hukum). Perspektif ini merupakan tinjauan dari bawah terhadap hukum (the bottoms up view of the law), hukum dalam perspektif ini meliputi obyek studi seperti misalnya kemampuan hukum, kesadaran hukum, penegakan hukum dan lain sebagainya.

Peraturan-peraturan yang terdapat dalam UU Korupsi mampu menjadi pijakan dan mengikat seluruh elemen masyarakat, atau mampu merekayasa masyarakat (social engineering), yang pada akhirnya menjadi pedoman dan alat kontrol bagi masyarakat terhadap prilaku menyimpang. Maka menurut Lon L. Fuller, peraturan yang mampu menjadi social engineering itu harus memiliki principles of legality sebagai berikut: (1) Sistem hukum harus mengandung peraturan-peraturan,artinya ia tidak boleh mengandung sekedar keputusan-keputusan yang bersifat ad hoc. (2) Peraturan-peraturan yang dibuat tersebut harus diumumkan.(3) Peraturan tidak boleh berlaku surut. (4) Peraturan-peraturan disusun dalam rumusan yang bisa dimengerti (5) Sistem tidak boleh mengandung peraturanperaturan yang bertentangan satu sama lain. (6) Peraturan tidak boleh mengandung tuntutan yang melebihi apa yang dapat dilakukan. (7) Peraturan tidak boleh sering diubah-ubah. Dan (8) Harus ada kecocokan antara peraturan yang diundangkan dengan pelaksanaan sehari-hari. Maka untuk mewujudkan law is a tool of social engineering perlu adanya penal policy pembentukan peraturan perundangundangan tentang korupsi yang tepat dari pembuatan kebijakannya, penegakkan hukumnya dan budaya hukum masyarakat untuk mencapai kepastian dan penegakan hukum di Indonesia. 


\section{DAFTAR RUJUKAN}

Adji, Indriyanto Seno, Humanisme dan Pembaharuan Penegakan Hukum, Jakarta: Kompas, 2009.

Andsbarcaboy.blokspot.co.id. Korupsi Dalam Pandangan Islam, 19 Maret 2013.

Arief, Barda Nawawi. Beberapa Aspek Pengembangan Ilmu Hukum Pidana (Menyongsong Generasi Baru Hukum Pidana Indonesia), (Semarang: Badan Penerbit Undip. 2007), 7-8.

Bashry, Teungku H. Hasanoel. Korupsi Dalam Tinjauan Fiqih Jinayati, Bandung: Pelita, 2009.

Berger, Peter L. Invitation to Sociologi: A Humanistic Prospective, Terj. Daniel Dhakidae. Jakarta : Inti Sarana Aksara, 1992.

Campbell, Tom. Tujuh Teori Sosial (Sketsa, Penilaian dan Perbandingan), Yogyakarta: Kanisius, 1994.

D.Schaffmeister, et.al. Hukum Pidana, Terj. J.E.Sahetapy. Yogyakarta: Liberty. 1995.

Dirksen, AA N Gede. Pengantar Ilmu Hukum. Fakultas Hukum Universitas Udayana, 2009.

Djaja, Ermansjah. Memberantas Korupsi Bersama KPK (Komisi Pemberantasan Korupsi). Jakarta: Sinar Grafika, 2009.

Hadisuprapto, Paulus. Deliquensi Anak Pemahaman dan Penanggulangannya, Malang: Bayumedia Publishing, 2008.

Hamzah, Andi. Perbandingan Pemberantasan Korupsi di Berbagai Negara. Jakarta: Sinar Grafika, 2005.

Hanafi, Ahmad. Azas-Azas Hukum Pidana Islam Jakarta: Bulan Bintang, 1993.

https://nasional.tempo.co

https://nasional.tempo.co 
https://nasional.tempo.co/read/news/2016/01/11/063735036/ suryadharma-ali-divonis-6-tahun-penjara

https://news.detik.com/berita/d-3359666/ketua-kpk-saya-dapatinfo-baru-kasus-sumber-waras-bpk-ajak-ketemu, 1-12-2016

https://nusantara.news/ini-asal-muasal-terbongkarnya-megaskandal-kasus-e-ktp/9-3-2017

Khodijah, Siti. Hukum Potong Tangan dan Pemberlakuannya Di Indonesia (Studi atas Pandangan Ulama Muhammadiyah dan NU), Skripsi, UIN Syarif Hidayatullah Jakarta, 2015.

Kulsum, Umi, "Kewenangan Komisi Pemberantasan Korupsi (KPK) dalam Melakukan Pemberantasan Tindak Pidana Korupsi" Jurnal Jure Humano, Volume 1, Nomor 3, 2009.

Kusumaatmadja, Mochtar. Hukum, Masyarakat, dan Pembangunan. Bandung: Bina Cipta, 1990.

Marpaung, Leden. Tindak Pidana Korupsi, Jakarta: Sinar Grafika, 1992.

Muladi. Kapita Selekta Sistem Peradilan Pidana. Semarang: Badan Penerbit Undip, 1995.

Muladi dan Barda Nawawi Arief. Teori-teori dan Kebijakan Pidana. Bandung: Alumni, 1998.

Noeh, Munawar Fuad. Islam dan Gerakan Moral Anti Korupsi, Jakarta: Zikhrul Hakim, 1997.

Rahardjo, Satjipto. Hukum Progresif, Sebuah Sintesa Hukum Indonesia, Yogyakarta, Genta Publishing, 2009.

Rahardjo, Satjipto. Hukum dan Perilaku. Jakarta: Kompas, 2009.

Rahardjo, Satjipto. Membangun dan Merombak Hukum Indonesia, Sebuah Pendekatan Lintas Disiplin, Yogyakarta, Genta Publishing, 2009.

Rahardjo, Satjipto. Membedah Hukum Progresif. Jakarta: Kompas Media Nusantara, 2008.

Rahardjo, Satjipto. Pemanfaatan Ilmu Sosial Bagi Pengembangan Ilmu Hukum, Bandung: Alumni, 1977. 
208 | Martha Eri Safira

Rahardjo, Satjipto. Ilmu Hukum (Cet. Keenam), Bandung: Citra Aditya Bakti, 2006.

Rasjidi, Lili dan Ira Thania Rasjidi. Dasar-dasar Filsafat dan Teori Hukum. Bandung: Citra Aditya Bakti, 2007.

Rasjidi, Lili dan Ira Thania Rasjidi. Pengantar Filsafat Hukum. Bandung: Mandar Maju, 2002.

Ridwan. Kebijakan Formulasi Hukum Pidana Dalam Penanggulangan Tindak Pidana Korupsi, Tesis, Program Pascasarjana UNDIP, 2010. 